\title{
Land development pressure on peri-urban forests: A case study in the Regional Municipality of York
}

\author{
By D. Puric-Mladenovic ${ }^{1}$, W.A. Kenney ${ }^{2}$ and F. Csillag ${ }^{3}$
}

Forests patches and forest fragmentation were quantified for seven area municipalities within the Regional Municipality of York for the period from 1975 to 1988 . This quantification made it possible to determine the extent of forest changes in space and time. In 1988 , forest cover shrank to $30 \%-50 \%$ of its 1975 extent. At the same time, the number of forest patches doubled or tripled and mean patch size and the area of interior (based on a $100 \mathrm{~m}$ wide edge) declined indicating a high rate of forest fragmentation.

Key words: development, fragmentation, remote sensing, forest

Des petits boisés et la fragmentation forestière ont été évalués pour sept territoires municipaux regroupés au sein de la Municipalité de York au cours d'une période allant de 1975 à 1988. Cette quantification a permis de déterminer le niveau de changement dans les boisés en terme d'espace et de temps. En 1988, le couvert forestier était réduit de 30 à 50 \% par rapport à ce qu'il était en 1975 . Au cours de la même période, le nombre de petits boisés a doublé ou triplé, et la dimension moyenne d'un boisé et la superficie interne (par rapport à une bande de 100 mètres de large) ont décliné, indiquant un haut taux de fragmentation.

Mots clés: développement, fragmentation, télédétection, forêt

\section{Introduction}

The once extensively forested landscape of the Regional Municipality of York (the Region) has been converted into an archipelago of relatively small woodland "islands," which are bordered by urban and suburban areas, agricultural land, or roads (Regional Municipality of YorK 1994). This land and forest transformation has happened through clearing for timber production, agriculture, and more recently, urban development. Remnant forest ecosystems have been broken up into smaller parcels that are changed in both their structure and function (Forman 1995). This type of deforestation is not unique to the regional municipality, but is more likely typical of urbanizing areas across Canada. Our objective is to use the Regional Municipality of York as a case study to examine spatial and temporal change in forest cover in such a landscape.

\section{Method}

The Region stretches from the City of Toronto's (post amalgamation) border in the south to Lake Simcoe and the Holland Marsh in the north. As an area on an urban-rural fringe, the area has undergone significant social, economic and environmental changes over the last 25 years, primarily as a result of urban expansion. Regional population increased from 165940 in 1971 , to 540000 in 1994, and it is projected to further increase to 1100000 by 2021. During the same period, the Region's forest cover was reduced from approximately $22 \%$ to $15 \%$ and fragmented into more than 3500 woodlots (Regional Municipality of York 1994). Not surprisingly, the most

\footnotetext{
${ }^{1}$ Faculty of Forestry, University of Toronto, 33 Willcocks Street, Toronto, On M5S 3B3. E-mail: dpuric@utoronto.ca

${ }^{2}$ Faculty of Forestry, University of Toronto, 33 Willcocks Street, Toronto, ON M5S 3B3. E-mail: a.kenney@utoronto.ca

${ }^{3}$ Department of Geography and Institute for Land Information, University of Toronto, Erindale College. Mississauga, ON L5L 1C6. E-mail: fcs@eratos.erin.utoronto.ca
}

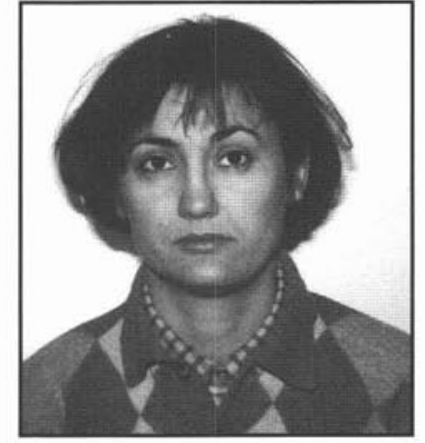

D. Puric-Mladenovic

dramatic change is within the urban and peri-urban ${ }^{4}$ areas, where total forest cover often does not exceed 5\%, and woodlots are often less than one ha.

The analysis of forest change was carried out at the area municipality level. Nine such municipalities are found in the Region. These communities are characterized by varying degrees of rural to urban land uses. Southern municipalities such as Vaughan, Markham, and Richmond Hill are almost entirely urbanized, while more northern ones such as King, Georgina, and East Gwillimbury are rural. Municipalities along the central corridor formed by Yonge Street are also highly urbanized. Consequently, we felt

\footnotetext{
${ }^{4}$ Peri-urban Forests are "forests" located in transitional zones between urban and rural landscapes that are significantly influenced by urbanization. They are on the outskirts or in the neighbourhood of urban areas. In many cases, the very nature of woodlands makes them appealing to the development industry, as the proximity to natural features is a strong marketing attraction.
} 
that there would be a difference in the patterns of forest change among the more urbanized areas at the leading edge of the greatest development wave as compared to that in the municipalities somewhat beyond.

The most recent imagery that was available for this project was from 1992. However, cloud cover in the central part of the Region made it unusable for this study. Coverage for 1975, 1985 and 1988 was virtually cloud-free. The images from 1988 covered the entire region, while the images from 1975 and 1988 failed to include the northern parts of the study area. Consequently, King Township and Georgina were excluded from the analysis because of this incomplete data.

Two TM (Thematic Mapper) scenes and one MSS (Multispectral Subsystem) scene were used. The MSS image from 1975 was obtained on June 22 and for this date the following three bands were available: MSS2, MSS3, and MSS4. The image from 1985 (September 20) had four bands available for classification: TM2, TM3, TM4, and TM5. The image from 1988 was from May 7 and had three bands: TM2, TM3, and TM4. All images were resampled to $25 \mathrm{~m}$ resolution.

For the 1975 scene, a forest cover map (FCM) was derived using hybrid classification. This map had an overall accuracy (Card 1982, Congalton et al. 1983, Congalton and Mead 1983 ) of $76 \%$. For the $1985 \mathrm{FCM}$, the forest was classified using supervised classification. This map had an overall accuracy of $87 \%$. The 1988 FCM was derived using hybrid classification and this map had an overall accuracy of $81 \%$. The maps were imported into GRASS 4.2 where the area was reclassified into forested and non-forested land to be consistent with the digitized forest cover from 1978 used for accuracy assessment. Seven separate digital layers showing forest cover of each of the analyzed area municipalities were created using GRASS 4.2 and exported to FRAGSTATS (McGarigal and Marks 1995) for analysis.

Forest transformation can come about through five major processes: perforation, shrinkage, dissection, fragmentation, and attrition (Forman 1995). All of these are at work in the area municipalities in the Region. The most dramatic of these, fragmentation, breaks up ecosystems into smaller parcels, changing both their structure and function (Forman 1995). Fragmentation indices are a quantitative measure of forest fragmentation that consider the spatial characteristics of patches, and they are useful for comparing different forest landscape changes on temporal and spatial scales. Fragmentation within the individual municipalities has been analyzed using landscape indices such as: a) percent forest cover, b) percent of the total area covered by the largest fragment, c) patch density (number of patches per 100 ha, d) mean patch size, e) the total core area (area of a forest fragment inside a $100 \mathrm{~m}$ buffer), f) core density (number of patches with core area,/100ha), and g) the percent of forest cover that is in core areas.

Changes in fragmentation indices over time were related to population growth and discussed from that point of view. As all of the municipalities that were examined differ in size and degree of urban development, population growth was expressed in terms of population density (persons per hectare).

\section{Results and Discussion}

The town of Aurora is situated within the central part of the region between Richmond Hill to the south and Newmarket to the north. The town covers an area of 4957 ha of which $42 \%$ is urbanized, and urbanization is expected to continue. The town has experienced rapid population growth and forest cover change from 1975 to 1988 (Statistics Canada 1981, Ministry of Treasury and Economics 1983, Regional Municipality of York 1994). Within the borders of the town of Aurora, forest cover changed from $32 \%$ in 1975 to 1988 and, to $12.2 \%$ in 1988 , The largest continuous forest patch occupied $10.2 \%$ of the total area of the town in 1975, while in 1988 the largest continuous forest patch occupied just $1.5 \%$ of the total area. In 1975, the forest cover in Aurora was composed of 158 fragments, while in 1988 the number of patches tripled to 457 . An increase in the number of forest patches was followed by a reduction in patch size. An average patch size of 10 ha in 1975 declined to 1.6 ha in 1985 , followed by a slight further decline to 1.3 ha in 1988 . As a consequence of forest fragmentation and shrinkage in the area, the number of core areas, decreased from 1975 to 1988. In 1975, the total number of core areas was 77 while in 1988 it was 28 . In $1975,15 \%$ of the total forest cover was forest interior, and in 1988 it was just $6.3 \%$. In less than 15 years, almost 200 ha of core area was lost. The density of core areas was reduced from $1.5 / 100$ ha in 1975 to 0.5 in 1988 .

Markham occupies an area of 21215 ha in the southern part of the region. More than $45 \%$ of the Markham area is urban land. The municipality grew from a population of 12231 in 1951, to 154000 in 1991 (Statistics Canada 1981, Ministry of Treasury and Economics 1983, Regional Municipality of York 1994). Over the last two decades in particular, Markham has experienced extensive population growth followed by an expansion of urbanization of its land base. This has had a significant impact on the amount of forest cover. Originally an agricultural municipality, it had $12 \%$ forested land in 1975 , but it has changed to an urban area with approximately $3 \%$ forest cover in 1988. This change affected both smaller and larger forest patches. For example, the largest continuous forest patch in 1975 occupied 275 ha or $1.3 \%$ of the total area, while in 1988 the area of the largest fragment was just 25.5 ha or $0.12 \%$ of the total area. Over thirteen years, forest fragmentation in the area was characterized by 905 forest patches in 1975 becoming 1141 by 1988 . This has resulted in the average patch size declining from 2.8 ha in 1975 to 0.5 ha in 1988 .

The detrimental impact of forest fragmentation is obvious when considering core areas. For example, from 95 core areas that represented $6.2 \%$ of the total cover in 1975, Markham's inventory declined to 16 core areas by 1988 . representing only $1.5 \%$ of the total cover. Core area density in 1975 was 1.0 core areas $/ 100$ ha and by 1988 it had declined to 0.2 cores.

Similar to the Town of Markham, $46 \%$ of the 27432 ha in the City of Vaughan is urban land. The population of the City of Vaughan increased 1.6 fold between 1951 and 1971 (Statistics Canada1981, Ministry of Treasury and Economics 1983, Regional Municipality of York 1994). The rate of population growth was particularly steep between 1971 and 1991. Even though the classified remotely sensed images for the Vaughan area did not cover the entire municipality (the southwest corner was not available) they were used to analyze forest cover changes in the remainder of the municipality. In 1975, forests covered $15.3 \%$ of the examined area, while in 1985 and 1988 forests covered $6.3 \%$ and $5.9 \%$. In 1975 , the largest continuous forest patch occupied $1.8 \%$ of the total area, while in 1988 the largest continuous forest patch occupied $0.4 \%$ of the total area. Patch density in the area increased from 2.2 patch- 
Table 1. A summary of the change in population density and some measures of forest fragmentation in seven area municipalities in the Regional municipality of York (Ontario) between 1975 and 1988

\begin{tabular}{|c|c|c|c|c|c|c|c|c|}
\hline Municipality & $\begin{array}{c}\text { Population } \\
\text { density }\end{array}$ & $\begin{array}{l}\text { Percent } \\
\text { forest } \\
\text { cover }\end{array}$ & $\begin{array}{l}\% \text { of the total } \\
\text { area occupied by } \\
\text { the largest patch }\end{array}$ & $\begin{array}{c}\text { Patch density } \\
\text { (patches per } \\
100 \text { ha) }\end{array}$ & $\begin{array}{c}\text { Mean } \\
\text { patch size }\end{array}$ & $\begin{array}{c}\text { Total core } \\
\text { area }\end{array}$ & $\begin{array}{c}\text { Core density } \\
\text { (core areas/ } \\
100 \text { ha) }\end{array}$ & $\begin{array}{c}\% \text { of forest } \\
\text { that is core } \\
\text { area }\end{array}$ \\
\hline Aurora & $62 \%$ & $-62 \%$ & $-85 \%$ & $189 \%$ & $-87 \%$ & $-84 \%$ & $-64 \%$ & $-95 \%$ \\
\hline East Gwillimbury & $40 \%$ & $-32 \%$ & $-59 \%$ & $55 \%$ & $-56 \%$ & $-42 \%$ & $-25 \%$ & $-63 \%$ \\
\hline Markham & $129 \%$ & $-75 \%$ & $-90 \%$ & $26 \%$ & $-81 \%$ & $-94 \%$ & $-82 \%$ & $-94 \%$ \\
\hline Newmarket & $73 \%$ & $-45 \%$ & $-2 \%$ & $74 \%$ & $-69 \%$ & $-52 \%$ & $-10 \%$ & $-73 \%$ \\
\hline Richmond Hill & $73 \%$ & $-65 \%$ & $-92 \%$ & $95 \%$ & $-82 \%$ & $-72 \%$ & $-74 \%$ & $-86 \%$ \\
\hline Vaughn & $169 \%$ & $-61 \%$ & $-76 \%$ & $41 \%$ & $-72 \%$ & $-85 \%$ & $-52 \%$ & $-89 \%$ \\
\hline Whitchurch-Stouffville & $33 \%$ & $-39 \%$ & $-37 \%$ & $63 \%$ & $-63 \%$ & $-25 \%$ & $-46 \%$ & $-54 \%$ \\
\hline
\end{tabular}

es per 100 ha in 1975 , to three patches per 100 ha in 1988 . Forest cover was distributed among 592 forest patches in 1975 , a figure that had increased to 838 by 1988 . The mean patch size in Vaughan had declined from 7 ha in 1975 to just 2 ha by 1988. The number of core areas also went down from 176 to 84 over this period. In $1975,16 \%$ of the forest cover was core area, and there were 2.4 core areas per 100 hectares. In 1988 , this changed to $6 \%$ or 0.3 core areas per 100 hectares.

Richmond Hill is situated in the central part of the region, on the east and west sides of Yonge Street. Richmond Hill is a smaller municipality than Markham and Vaughan with an area of 10228 ha. However, this municipality has a higher population density than the other two municipalities. For example, in 1991 Richmond Hill had 7.8 persons per hectare, while Markham had 7.3 and Vaughan had 4.1 persons per hectare. It is expected that in 2021 Richmond Hill will have almost 20 persons per hectare of land (Statistics Canada 1981, Ministry of Treasury and Economics 1983, Regional Municipality of York 1994). Currently, $57 \%$ of the area of Richmond Hill is urbanized, with a total forest cover of 1088 ha or $13.6 \mathrm{~m}^{2}$ per person. Forest cover in this area was substantially changed from 1975 to 1988 and declined from $31 \%$ to $10.6 \%$. The largest continuous forest patch occupied $15 \%$ of the area in 1975 . By 1988 this value was $1.2 \%$. From 1975 to 1988 , the number of forest patches in the area was almost doubled, and patch density went from 4.4 to 8.9 patches per 100 hectares. The average patch size of 6.8 ha decreased to $1.2 \mathrm{ha}$. All of these were reflected in a decrease in the number of core areas with a loss of over $65 \%$ of the 528 core areas between 1975 and 1988. Core area density declined by $75 \%$ over this period.

Newmarket has been developed on the east and west sides of Yonge Street, following the north-south expansion of urban development in the Region. The municipality has a total area of 3,884 ha, of which $90 \%$ has been developed. It also has one of the highest population densities in the region, with 11.7 persons per hectare. It has been predicted that this will increase to 19.3 persons per hectare by 2021 (Statistics Canada 1981, Ministry of Treasury and Economics 1983, Regional Municipality of York 1994). In 1988, this municipality had approximately 347 ha of forests, which is $9 \%$ of the total area. Forests covered $16.4 \%$ of the municipality in 1975 but only $10.2 \%$ by 1985 . The size of the largest continuous forest patch stayed in the range of 2.5 to $3 \%$ of the total area, suggesting that larger forest patches were less affected by development than smaller ones. In 1975, forest cover in Newmarket was composed of 185 patches, while in 1988 it consisted of 322 patches. This resulted in an increase in patch density from 4.7 to 8.2 .

Average patch size in 1975 was 3.4 ha while in 1985 it was $1.3 \mathrm{ha}$, and in 1988, it was 1.1 ha. Forest fragmentation also has an impact on the number of core areas as well as on total core area within the forest. The total number of core areas was 32 in 1988, down from 69 in 1975 . Core areas occupied $11 \%$ and $9 \%$ in 1975 and 1988. From 1975 to 1988 , almost 40 ha of core area was lost. Density of core areas was reduced from 1.8 in 1975 , to 0.8 over the 13 years.

Whitchurch-Stouffville is a rural municipality in the east end of the Region. It consists of smaller communities and woodlands imbedded in a matrix of agricultural land. It occupies a total area of 21022 ha and has a population density less than one person per hectare. Total forest cover in the area is 4259 ha, which is $20 \%$ of the total land area. Although WhitchurchStouffville is a rural area and under much less pressure from urban development than other municipalities, it has also experienced forest cover fragmentation and reduction. In this area, population growth and forest cover changes were less intense than in the cases of previously discussed municipalities (Statistics Canada 1981, Ministry of Treasury and Economics 1983, Regional Municipality of York 1994). Approximately 33\% of the total area of the Whitchurch-Stouffville municipality was not the same as in Markham or Vaughan, the forest cover in Whitchurch-Stouffville was reduced to $20 \%$ in 1988 . The largest continuous forest patch occupied $10 \%$ of the area in 1975 while in 1988 it occupied $6.4 \%$ of the entire area. In this municipality, the number of forest patches increased from 850 in 1975 , to 1300 in 1988 . Average patch size of 8 ha decreased to an average of 3 ha. The number of core areas in WhitchurchStouffville went from 329 in 1975 , down to 179 in 1988. However, the decrease in total core area was not as drastic in this area as was the case in more urbanized municipalities. A total of 1085 ha of core areas decreased to 829 ha, indicating that the highest rate of change happened within smaller woodlands.

East Gwillimbury is another rural municipality in the northern part of the region. It has a total area of 24764 ha, and a population density of 0.7 persons per hectare (Statistics Canada 1981, Ministry of Treasury and Economics 1983, Regional Municipality of York 1994). It is characterized by the most extensive and most continuous forest cover of the all municipalities within the region. From all of the examined areas, this municipality experienced the lowest rate of forest cover change in past twenty years. The total forest cover in this area decreased from $36 \%$ in 1975 , to $25 \%$ in 1988 . Almost $50 \%$ of the total forest cover in 1975 was contained as one large fragment. However, this changed in 1988 when only $30 \%$ of the total forest was contained in one single patch. In 1975 , forest cover in this are was composed of 770 patches, and by 1988 this had increased to 1191 , representing an increase in density from 3.1 to 4.8 patches per 100 hectares. Mean patch size was 178 ha in 1975 and 
changed to 63.3 ha by 1988 . From 1975 to 1988 , the total core decreased from 9002 ha to 6141 ha, and at the same time the number of core areas decreased from 258 to 194. More than $34 \%$ of the forest cover, in 1975, was forest interior, while in 1988 this declined to $30 \%$.

Table 1 summaries the rates of change (\% change from 1975 to 1988) for these fragmentation indices. A Spearman's Rank Correlation on the change in population density $v s$. the fragmentation indices yielded negative values for all $\mathrm{r}_{\mathrm{s}}$, however none were statistically significant at $a=0.05$.

\section{Conclusion}

Fragmented woodlands in the peri-urban environment potentially suffer from degradation resulting from invasion by alien flora and fauna (including cats and dogs), soil compaction, grade changes, air pollution, altered water tables, etc. At the landscape level, the number of woodlots increases and the average size decreases with a concomitant increase in edge habitat and a decrease in interior.

This case study has examined the changes in some indices of forest fragmentation in one rapidly urbanizing region of the largest conurbation in Canada. Some urban municipalities in the study have barely $5 \%$ forest cover consisting mainly of small isolated patches. Even well beyond the zone of the greatest current development, the spatial extent and structure of the forest cover has been drastically changed from that present a few decades ago.

In landscapes where woodlands are embedded in an urbanrural matrix, such as those considered in this case study, the decision-making processes for forest management, urban development, and agriculture must consider the ecological values of entire landscapes and not just single woodlots. (Mueller-Dombois and Ellenberg 1974, Dorney and Leitner 1985, Smith and Theberge 1987, Küchler and Zonneveld 1988, Bailey 1996, Gray et al. 1996, Puric-Mladenovic and Kenney 1996). This is a challenge for land-use planners and managers in any situation, but the fragmentation of land ownership in the peri-urban forest makes the situation more difficult. With limited resources for protecting and enhancing woodlands, most of which are in private ownership, the setting of conservation priorities becomes essential. Efforts to conserve or protect woodlands will only slow the rate at which they are lost from the landscape. Only if our planning efforts actively work towards expanding or enhancing woodlands will we truly reverse the trend illustrated in this case study.

In a temporal sense, if we consider the "value" of a particular fragment or group of fragments only within the context of the current resource, we may again limit our ability to reverse the trend in forest loss and degradation. If, on the other hand, we incorporate some aspects of the potential natural vegetation in the decision-making process, priorities for conservation and, perhaps more importantly, restoration and enhancement may change.

We are currently working towards the development of a GISbased procedure to assist planners in a dynamic approach to setting priorities for woodland conservation. Using historical and contemporary vegetation data, predictive vegetation mapping, and gap analysis we hope to be able to provide decision makers with additional tools to effectively allocate conservation and enhancement efforts in the peri-urban forest.

\section{Acknowledgements}

The authors would like to thank the Regional Municipality of York, the Canadian Forest Service, EJLB Foundation and NSERC for their support.

\section{References}

Bailey, R.G. 1996. Ecosystem geography. Springer-Verlag New York, Inc. 204 p.

Card, D.H. 1982. Using known map category frequencies to improve estimate of thematic map accuracy. Photogrammetric Engineering and Remote Sensing. 48(3): 431-439.

Congalton, R.G. and R.A. Mead. 1983. A Quantitative Method to Test for Consistency and Correctness In Photointerpretation. Photogrammetric Engineering and Remote Sensing 49(1): 69-74.

Congalton, R.G., R.G. Oderwald and R.a. Mead. 1983. Assessing Landsat classification accuracy using discrete multivariate statistical techniques. Photogrammetric Engineering and Remote Sensing. 49(12): 1671-1678.

Dorney, J.R. and L.A. Leitner. 1985. Woodlot scale: a method for rapid assessment of woodlot values. Environmental Management. 9: 27-34.

Forman, R.T.T. 1995. Land mosaic: the ecology of landscapes and regions. University Press, Cambridge. $632 \mathrm{p}$.

Gray, P.A., D. Cameron and D. Kirkham. 1996. Wildlife habitat evaluation in forested ecosystems: some examples from Canada and United States. In R.M. DeGraaf and R.I. Miller (eds.). Conservation of Faunal Diversity in Forested Landscapes. pp. 407-506. Chapman and Hall. London, UK. 633 p.

Küchler, A.W. and I.S. Zonneveld. 1988. Vegetation mapping. Kluwer Academic Publisher. Dordrecht, Netherlands. 635 p.

McGarigal, K. and B. Marks. 1995. FRAGSTATS: Spatial pattern analysis program for quantifying landscape structure. General Technical Report PNW-GTR-351. USDA Forest Service, Pacific Northwest Research Station. Portland, Oregeon. 122 p.

Ministry of Treasury and Economics. 1983. 1981 census data by provincial electoral districts. Ministry of Treasury and Economics, Statistical Services Branch. Toronto. 1983.

Mueller-Dombois, D. and H. Ellenberg. 1974. Aims and methods of vegetation ecology. Wiley, New York. 547 p.

Puric-Mladenovic, D. and W.A. Kenney. 1996. Potential Natural Vegetation as a Guideline for Urban Forest Planning. The paper was presented at the CCEA (Canadian Council on Ecological Areas)/CSLEM (Canadian Society for Landscape Ecology and Management) Home Place Conference, September 29-October 1, Regina, Saskatchewan.

Regional Municipality of York. 1994. Official plan. The Regional Municipality of York. 79 p.

Smith, G.R., and J.B. Theberge. 1987. Evaluating natural areas using multiple criteria: theory and practice. Environmental Management. 11(4): 447-460.

Statistics Canada. 1981. Census of Canada, 1976. General population, housing, household, family and labour force data. Ontario/Customer Services Section, Census Operations Division, Social Statistics Field, Statistics Canada. Statistics Canada. Ottawa. 